\title{
JOURNAL.RU
}

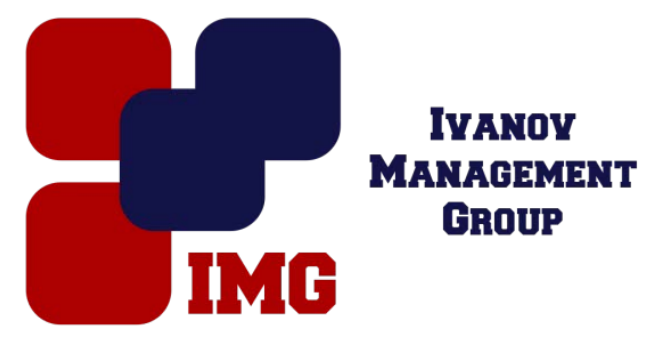

Гончарук Н.Ф. ГБОУ ВПО СибГМУ Минздрава России Томск, Россия

doi: 10.18411/lj-31-01-2017-1-01

idsp 000001:lj-31-01-2017-1-01

\section{Факторы, влияющие на отношение обучающихся к занятиям физической культурой и спортом}

С каждым годом физическая активность и спорт все в большей степени проникают в повседневную жизнь, увеличивается число людей, приобщающихся к спорту, растёт количество и качество спортивных сооружений. В РФ в 2012-2015 гг. происходил рост доли населения, систематически занимающегося физической культурой и спортом, который составлял $41,8 \%$, в то же время увеличилоськоличество спортивных сооружений на 13,3 \%[5].

Спорт и физическая культура являются многофункциональным механизмом оздоровления людей, самореализации человека, его выражения и развития. Поэтому основополагающей задачей государственной политики является создание условий для роста благосостояния населения Российской Федерации, национального самосознания и обеспечения долгосрочной социальной стабильности [4].

Цель:изучить факторы, влияющие на отношение к занятиям физической культурой и спортом обучающихся МАОУ СОШ № 37 города Томска.

Опрос 325 обучающихся проведён в 2016 году на основании анкеты, разработанной Министерством спорта, туризма и молодёжной политики РФ [1].

Результаты опроса позволили установить, что школьники 5-11 классов практически в одинаковой мере уделяют время спорту. В среднем девушки 6-х, 910 и юноши 5-7, 10-11 классом занимаются от 4 до 6 раз в неделю, в то время как девушки 5-х, 7-8, 11-х, классов занимаются от 1 до 3 раз в неделю. При этом девушки 8-11 классов $(43 \%, 56 \%, 60 \%, 46 \%$ соответственно), своё здоровье оценивают, как удовлетворительное, а девочки 5-7 классов $(70 \%, 48 \%, 38 \%)$ считают, что они совершенно здоровы. В то же время мальчики 8-х, 10-11 классов $(50 \%, 62 \%, 48 \%)$ оценивают своё здоровье как удовлетворительное, а юноши 5-7, 9-х классов $(61 \%, 47 \%, 73 \%, 52 \%$ соответственно) считают, что они абсолютно здоровы.

В школе обучающихся привлекают к занятиям физической культурой и спортом с помощью такого существующего фактора, как действие на постоянной основе спортивных секций: баскетбол, легкая атлетика, ЛФК, карате, которые в среднем проходят 3 раза в неделю. Доля обучающихся, самостоятельно 
занимающихся физической культурой и спортом, из числа опрошенных составляет $92 \%$. Девушки 11-х, 9-х, 6-х классов предпочитают утреннюю гимнастику, девушки 10-11, 7-х классов предпочитают катание на лыжах и коньках, а девушки 5-х классов уделяют время плаванию. Юноши 9-11 классов отдают предпочтение занятиям на тренажёрах, мальчики 5-8 классов - футболу.

Цели, которые преследуют обучающиеся при занятиях физической культурой и спортом различны. Девушки 5-7 и юноши 5-8, 11-х классов желают поддержать и улучшить своё здоровье, тогда как девочки 8-11 классов и молодые люди 9-10 классов стремятся сохранить и улучшить своё телосложение. Юношей 5-8,10-11 классов и девушек 5-10 классов ничто не сдерживает от активных занятий физкультурой и спортом, однако у юношей 9-х классов и девушек 11-х классов наблюдается отсутствие свободного времени для занятий физической культурой и спортом.

В будущем 94 \% обучающихся из числа опрошенныхпланируют начать заниматься различными видами спорта. Например, юноши 8-х, 11-х классов и девушки 10-х классов хотят начать кататься на лыжах и коньках, молодые люди 10-х классов и девочки 8-х классов думают заняться плаванием, мальчики 6-х классов - волейболом, 5-х классов - футболом. В то время девушки 11-х классов оздоровительным бегом, 6-х классов - гимнастикой, 5-х классов- велоспортом. Однако, к сожалению, у девушек и у юношей 7-х и 9-х классов отсутствует какоелибо желание в ближайшее будущее начать заниматься различными видами спорта, в отличие от других обучающихся.

Занятия физической культурой и спортом требуют финансовых вложений. Так, у более 50\% обучающихся 5-11 классов затраты отсутствуют, лишь у малого количества девушек и юношей наблюдается затраты, где они составляют в среднем от 1000 до 3000 рублей в месяц, и около 20\% юношей и девушек тратят на занятия не больше тысячи рублей.

\section{Вывод:}

В заключение можно отметить, что такие факторы, как наличие спортивных секций в школе, свободное время, желание совершенствовать своё здоровье и улучшать телосложение, позволяют школьникам формировать положительное отношение к занятиям физической культурой и спортом. 


\section{Литература}

1. Опросный лист для выявления отношения населения страны к занятиям физической культурой и спортом, разработанный и утверждённый Минспорттуризмом России. [Электронный pecypc] / Режим доступа: sport.boradmin.ru

2. Условия, влияющие на занятия физической культурой и спортом. [Текст]: всероссийская итоговая 75-я студенческая научная конференция им. Н.И. Пирогова (Томск, 25-27 апреля 2016 г.): сборник материалов/ под ред. Г.Э. Черногорюка. Томск: Изд-во СибГМУ, 2016. - С. 427-428.

3. Федеральная целевая программа «Развитие физической культуры и спорта в РФ на 2015-2020 годы» [Электронный ресурс] / Режим доступа: http://www.minsport.gov.ru/activities/federal-programs/2/26361/

4. Дуплинская Е. Б., Селиванов К. С. Приоритеты государственной политики в финансировании физической культуры и спорта в РФ // Молодой ученый. - 2014. №11. - C. 204-207.

5. Показатели для оценки эффективности деятельности органов исполнительной власти субъектов Российской Федерации за период 2012-2014 гг. [Электронный ресурс] / Министерство спорта РФ- Режим доступа: http://www.minsport.gov.ru/sport/physicalculture/statisticheskaya-inf/ 